\title{
CORPORATE CHALLENGE FOR TRANSFORMATIVE APPROACH IN PROCESS OF SOCIAL VALUE CREATION
}

\author{
Kate Trajkova ${ }^{275}$ \\ Marko Andonov 276 \\ Zoran Mihajloski ${ }^{277}$
}

https://doi.org/10.31410/itema.2018.761

\begin{abstract}
In conditions of strong global pressure from the socio-economic and environmental demands of the environment, the transformative model of creating social values becomes a growing challenge for the business community. The transformative approach to socially responsible action focuses on the macro (national) level implies the interconnection of socialeconomic and environmental systems, for which, through deeper changes in national strategies, management is optimized for achieving higher changes in the human and eco-system. This level of approach has the key to essential changes at the societal, organizational and individual levels. The transformative approach to CSR, known as the DNA model for CSR 2.0 is the new holistic approach to strategizing the concept in the current economic conditions - ages of responsibility. The article analyses and evaluates CSR 2.0, and also shows basic differences between the classic and new approach for the concept strategy.

The focus of scientific interest is degree of creating CSR policies based on the DNA 2.0 model. Research was conducted in 155 Macedonian companies from a deliberate target sample of companies. According to the principles of general methodology and specifics of the subject, research was conducted on two levels: theoretical and empirical level.
\end{abstract}

Keywords: CSR policy, CSR strategic dimension, Social shared values

\section{INTRODUCTION}

I

$\mathrm{n}$ order to ensure sustainability of the national economy as well as create preconditions for equal participation of organizations in the competitive market globally, countries around the world adopt various economic policies that refer to the purchasing power of the market, the export of raw materials as a basis for survival, the threat of multinational companies, corporate vulnerability, global competitiveness, technology development, etc. However, social changes, with social and political dimension, are a consequence of the intensity of globalization and liberalization, are questioning and emphasizing the responsibility of organizations towards society. In addition to the attention and care that the global business has from the influence of the global economic processes on sustainability and competitiveness, in developing its organizational and business strategies, it simultaneously focuses on the impact they have on the immediate environment, that is, the impact of business activities on the society. Over the past three decades, intensive business development driven by the pressure to generate surplus profits confronts world business leaders with the watchful eye of the public about their relationship and influence on social, ethical, economic and environmental aspects. In order to establish a balance between business activities and care for internal and external stakeholders (employees,

\footnotetext{
${ }^{275}$ University American College Skopje, Street: Treta Makedonska Brigada no. 60 Skopje, Macedonia

276 University American College Skopje, Street: Treta Makedonska Brigada no. 60 Skopje, Macedonia

${ }^{277}$ University American College Skopje, Street: Treta Makedonska Brigada no. 60 Skopje, Macedonia
} 
customers, consumers, suppliers, partners, investors, trade unions, the local community, public authorities, the NGO sector, etc.), the organizations develop socially responsible (SR) approach to action.

Corporate Social Responsibility (CSR) is a complex, multi-faceted phenomenon, which by its nature is a kind of link between business and the social environment (with a social, economic and environmental dimension). For the modern world, CSR is a new model of economic democracy, whose political function is mirrored in pursuing a sustainable development based on economic, environmental and social justice.

With the help of the SR approach, organizations show an innovative approach in their actions towards social and economic challenges, through cooperation with internal and external stakeholders, thus improving their social performance. For internal corporate action, the CSR is a multidimensional philosophy of life in managing the system on a voluntary basis. Aware of the role of their action in and on society, as well as the benefits of a pro-active approach to SR, companies in EU Member States promote their CSR strategies using their instrumental value to send signals to stakeholders about the existence of the social interest, as well as for returning investment in the future based on the volunteer approach.

\section{CORPORATE APPROACH TO SOCAL RESPONSIBILITY}

The application of the SR in the organization is a tool for channeling the pressure from the various groups of stakeholders. Development within the organization transits a series of shortterm reactions ranging from defensive to proactive forms of social behavior. Forms of behavior that the organization will display within the range can be followed by intensive media coverage, be of minimal value to society and without strategic benefit to the business (Porter \& Kramer, 2006). The impression is still that the organizations, in the current socio-economic and social conditions, although they understand the contribution of the SR to social progress and the development of corporate image, still have a defensive role. Militaru \& Ionescu (2006) point out that, in certain circumstances, organizations consider the SR more of a peril, for an external risk of management and with the least possible investment, rather than for the possibility of a valuable social influence or competing difference. The offensive role of organizations is changing with investments of billions of dollars a year in philanthropy and in SR initiatives. The offensive approach to CSR differentiates the reputation of the organizations, but cannot protect it, unlike the defensive, which can protect the reputation, but not to differentiate it from the competitive environment. For success in the business community, Militaru \& Ionescu (2006) point out the need for both approaches to CSR, which requires commitment to achieving social goals that meet social expectations. In their study they point out that organizations in their actions, in order to provide their own benefit in terms of reputation and competitive advantage, need to replace the defensive with an offensive approach to CSR. With the offensive approach and through rising social investments, organizations have impacts that exceed social expectations, compared to the defensive approach, by which the organization achieves significant short-term gains and impacts on the environment that are under social expectations. For Zadek (2002), the levels of manifestation of CSR differ depending on the tools and processes through which the concept is applied, which can be also called generational differences in CSR. They distinguish three generations of CSR legal compliance: the first generation of a low-level business case, the second generation of strategic CSR, and a third generation of changed competitive advantage. Modern management within the model of a business case acts according to the principles of the so-called 'Doing good'. Zadek (2002) 
support the view that the "win-win" movement provides profits through "good acting" as one single and most important way of doing business.

Gaberman (2007) distinguishes five types of organizations based on the way they perceive and implement the CSR program: "Unsensitized" organization - one approach when the organization does not recognize voluntary social responsibility and remains unconnected. These include organizations that adhere to the legislation, only in order not to be a burden on society. "Philanthropic" organizations - act on the basis of moral values and choices of the founder. Charity is not part of the corporate strategy and does not communicate with the public. "Random sponsor" is the type of organization that tends to form a good corporate reputation through a given sponsorship. Activities are selected on the basis of proposals and pressure from society, as well as from the offered public opportunities, without any further interaction with the broader strategy. "Permanent sponsor" is a type of organization that aspires to contribute to improving the physical and social environment. They choose projects that have a connection to the corporate strategy and involve employees. The active "corporate citizen" is an organization that places CSR at the heart of corporate philosophy and restructures the decision-making process in order to serve the concept. In cooperation with other sections, it requires co-operation in order to contribute to sustainable development without requiring short-term profit. Employees in this type of organization are not only internal observers but also an active component in building CSR programs.

The organization's approach to the SR is determined by the attitude of the organization for the SR, which reflects the way managers and employees of the organization see their duty and commitment to make decisions that will protect, enhance or improve the well-being of stakeholders and society in general (Jones \& George, 2008). The degree of commitment of the organization to the SR is variable and ranges from low to high. The extremely low commitment of the organization to the SR denotes the approach of obstructionism, in which management and employees choose not to apply to the SR way, more precisely behave unethically and illegally, and at the same time do everything that cannot be recognized by their stakeholders for their behavior and from society. Unethical behavior is a major feature of the obstructive approach. Despite attempts at unethical behavior and taking into account only personal interests in relation to health and well-being of stakeholders and above the law, most of the companies that have focused on this approach from the continuum are no longer part of the market. Organizations that manifest their extreme attachment to ethical behavior in their actions show a defensive approach to the SR. The company and managers in this modality behave ethically to the extent that they remain within the scope of the law and legal requirements and do not try to be above the legal provisions. Otherwise, these managers, when making ethical decisions, prioritize their personal interests at the expense of the interests of other stakeholders. Responsibility for acting organizations is most often manifested through volunteer programs for employees, which aim to provide employee satisfaction and motivation and better productivity without being exposed to additional investments. In this way, they abide by the legislation and are protected against possible punitive repercussions. The national economic condition moves the need of the organizations towards a higher stage of the SR, which is why they manifest their orientation towards the approach of adjustment. The company and the management, in addition to the consent of the organization's ethical behavior as a whole, balance the interests of the stakeholders. At the same time, the demands of the shareholders / managers are seen in a joint manner with the interests of the other stakeholders. Management makes choices of policies and activities that are reasonable for the social environment. Large organizations / companies are oriented towards this approach, mostly to ensure competitive advantage on the market through the SR of its operation. The adaptation approach corresponds 
with the years of philanthropy in which the access to the SR is termed as charity SR. The organizations that achieve this stage from the development of the access to the SR provide donations and sponsorships for various socio-social and environmental reasons in order to support the community or civic organizations. In the years of misrepresentation, organizations apply the SR for media promotion and as an option to improve their own brand, image and reputation, while the approach itself is also called a promotional approach to the SR. The promotional approach to the SR can be built on the basis of the charity and strategic approach to the SR. Organizations and management, with the active acceptance and application of the SR way of behavior, demonstrate a proactive approach. Through this approach, the organization teaches about the interests of different stakeholder groups using its own internal organizational resources and promotes the interests of stakeholders / managers as well as other stakeholders (Jones \& George, 2008). Depending on the economic management period, access to the SR implies linking the OO activities with the core business activities (e.g. Coca-Cola water management policy), which is achieved through the support of the social management systems environmental issues that encompass one cycle of policy development for SR, goal setting, stakeholder interaction, program implementation, audit and reporting.

\section{TRANSFORMATIVE APPROACH IN PROCESS OF SOCIAL VALUE CREATION}

The current economic period known as the years of responsibility from organizations expects to identify and signal the roots of current unsustainability through the development and stimulation of the development of an innovative culture and a revolutionary approach to processes and products / services and through lobbying for progressive national and international policies.

According to Visser (2011), organizations' access to SR is developed through five global economic periods called: years of greed, philanthropy, misrepresentation, management and accountability. In each of these periods, different approaches were developed, degrees of development of the SR, which are called: defensive, charitable, promotional, strategic and transformative approach, which is also referred to as CSR 2.0, systematic CSR or radical CSR. According to him, organizations are striving for a developmental shift in the approach to SR throughout the period, although sometimes they also apply activities that are characteristic for several economic periods and approaches. Contemporary management, in addition to encouraging the business community to transition to transformational CSR, as the peak of the current economic period called years of responsibility tends to develop a new holistic model of CSR called DNA of CSR 2.0. The strategic approach to SR is operationalized at the macro (organizational) level (organizational support for social and environmental issues) and, as Visser (2011) says, signifies the compliance of the concept of responsible action with the organizational strategy and the inclusion of the initiatives for SR behavior (social and environmental issues) in the strategy (without making any changes to the strategy). In contrast, the transformative approach to SR focuses on the macro (national) level and implies the interconnection of social and social systems and environment, for which, with deeper changes in national strategies, management is optimized for achieving higher changes in human and in the eco system. This level of approach has the key to essential changes at the societal, organizational and individual levels.

For the highest stage of SR approach in the current economic conditions, called years of responsibility, the transformative approach to SR, also called the DNA model for CSR 2.0, is considered. For Visser (2011), it is the new holistic model of CSR, for which little is said in the literature given its inception over the last decade. It is developed following the example of 
biological DNA. The bases of the DNA of responsibility are: creating values, good behavior, social contribution and environmental integrity. The most developed form of the SR approach, in addition to its orientation towards responsibility, equally applies to sustainability. The title of the approach is an acronym of the five main principles for its achievement: Creativity $(C)$ a principle that provides the production of a wider framework of opportunities for solving complex socio-social and environmental problems compared to the opportunities provided by the standards for SR, including ISO 26000. Scalability $(S)$ - a principle that refers to the need for remodeling the programs - case studies for the SR prior to their introduction into an organization. Responsiveness $(R)$ - a principle that requires greater cross-sectoral collaboration and stake-oriented approach to stakeholders at any organizational level, with an unfortunate transformative response to specific industries as to whether their behavior is part of the problem or part of the possible solution to social problem. Dual activity (2) - a principle that means "Think globally, act locally", referring to internalizing international norms and standards in a local context and finding local options and solutions that are appropriate to the cultural environment. Using the principle, it is possible to move along the continuum from the point "or-or" the world in one size that suits everyone to the point "two-and-one" force in the world of diversity. Circle (0) - the principle of a global economic and commercial system that requires it to overcome all the weaknesses in the design of products, to protect the world from unlimited resource and environmental waste generation. The principle tends to overcome the weaknesses of the design by creating inherently good products.

$\mathrm{H}$ : Private sector organizations differ from public sector organizations in terms of access to the process of creating SR policies.

\section{METHODOLOGY}

\subsection{Research approach and instrument}

The current growing interest in CSR, both researchers and managers, as well as scientists and practitioners, is a landmark of today. The interest of practitioners for CSR is one step ahead of the SR relationship with the competitive advantage in the context of the developmental economy. Scientific research, from a methodological point of view, has been realized on a theoretical and empirical level, according to the principles of the general methodology and specifics of the subject of research.

The goal of the research is identification of the access of the organizations in the Republic of Macedonia to the SR. For the purposes of the research, in terms of research strategy, the strategy of research that is most closely associated with the deductive approach is engaged. In addition, in order to collect the necessary qualitative data, which are analyzed quantitatively, by applying descriptive and deductive strings, a questionnaire with 36 claims on the process of creating the SR policies is applied.

Taking into account the specifics of the predefined group of respondents, a deliberate (target) copy of the Macedonian enterprises and state institutions (organizations) has been designed, contacted in writing and electronically. When designing a sample of respondents, account is taken of their suitability with respect to the practice of the concept and the already demonstrated expertise in the subject of research. 
For the purpose of the research, the descriptive and exploitative method was used, which allowed identification of the general characteristics of the investigated phenomenon, as well as determining the causality between the examined variables of the hypothetical framework.

The univariate level of analysis was achieved by applying descriptive statistics, depending on the level of the measures taken for the independent and dependent variable (e.g. general distribution of responses, central tendency measures, dispersion measures, graphic display).

\section{a. Corporate approach to SR}

Graphic illustration (Graph 1) of the data in Table 1 refers to the percentage of organizations to each of the four approaches that the organizations of the sample $(\mathrm{N}=155)$ have in relation to the process of creating the SR policies. Namely, 1.94\% of the organizations from the sample manifested the approach of obstructionism towards the process of creating SR policies, $26.45 \%$ demonstrate a defensive approach, $34.84 \%$ of the organizations from the sample demonstrate the approach to adapting to the SR policies, while the largest percentage of organizations, i.e. $36.77 \%$ proactive approach to the process of creating SR policies.

Table 1: Distribution of organizations according to the approach to the process of creating the SR policies

\begin{tabular}{|c|c|c|c|c|}
\hline $\begin{array}{c}\text { Corporate approach } \\
\text { toward CSR }\end{array}$ & obstructionism & defensive & adjustment & proactive \\
\hline$\%$ & 7.74 & 32.26 & $(38.06)$ & 29.94 \\
\hline
\end{tabular}

Graph 1: Percentage distribution of organizations according to the approach to the process of creating CSR policies

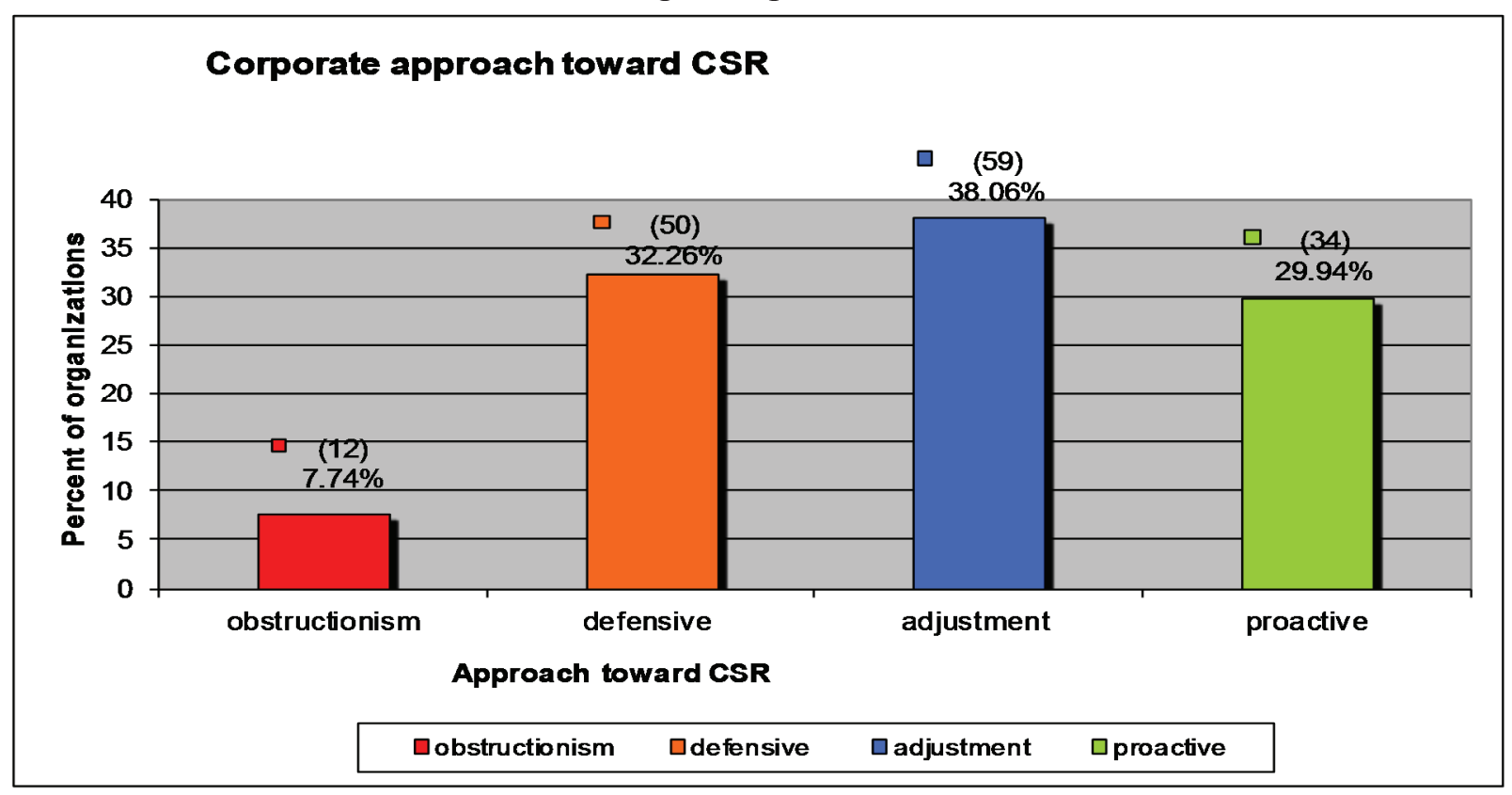


Table 2: Cross tabulation of organizations with different capital origin toward approach to CSR policy creation

\begin{tabular}{|c|c|c|c|c|c|}
\hline \multirow{2}{*}{$\begin{array}{c}\text { Corporate approach to } \\
\text { CSR }\end{array}$} & Obtructivism & defensive & adjustment & proactive & \multirow{2}{*}{ Total } \\
\hline & $\begin{array}{c}\text { interval Min- Max } \\
(1.20-2.10)\end{array}$ & $\begin{array}{c}\text { interval Min- Max } \\
(2.11-3.00)\end{array}$ & $\begin{array}{c}\text { interval Min- Max } \\
(3.01-3.90)\end{array}$ & $\begin{array}{c}\text { interval Min- Max } \\
(3.91-4.80)\end{array}$ & \\
\hline \multicolumn{6}{|l|}{ Corporate origin } \\
\hline Private sector & 1 & 4 & 33 & 49 & 87 \\
\hline$\%$ & 1.15 & 4.60 & 37.93 & 56.32 & 100.00 \\
\hline Public sector & 2 & 37 & 21 & 8 & 68 \\
\hline$\%$ & 2.94 & 54.41 & 30.88 & 11.76 & 100.00 \\
\hline \multicolumn{5}{|c|}{ Total } & $155 / 100$ \\
\hline
\end{tabular}

Graph 2: Organizational access to the process of creating the SR policies

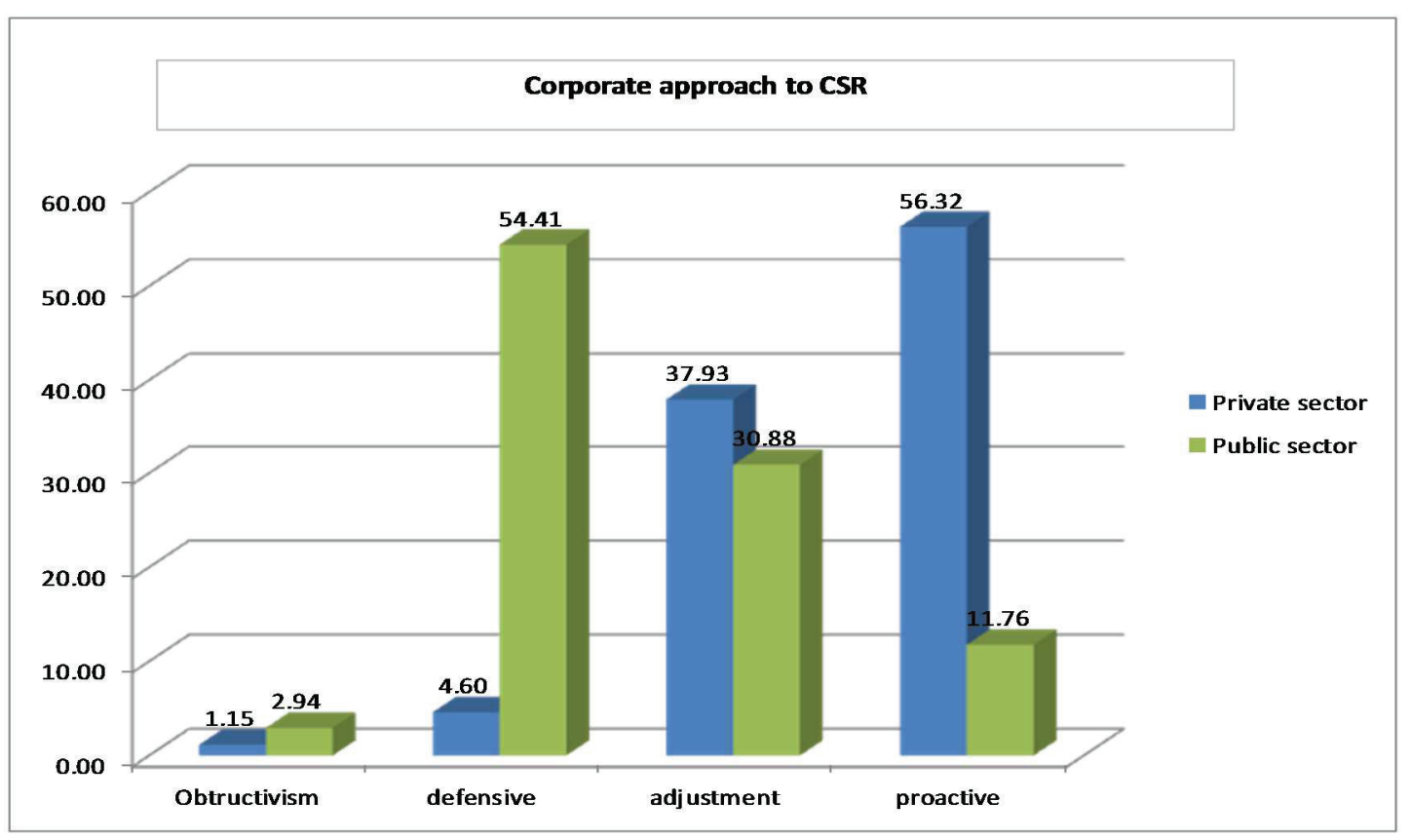

The growth of organizations with different origin of capital in relation to access to the subject of research (Table 2 and Chart 2) clearly indicate that $37.93 \%$ of those from the private sector and $30.88 \%$ of those in the public sector apply the approach to adapting to the SR policies. Private sector organizations, according to the percentage of the manifestation (56.32\%), note a development trend toward a proactive approach. The negative trend of the manifestation regarding the defense approach is shown by the public sector organizations, with a percentage of $54.41 \%$.

Table 3 and Table 3 a presents the descriptive statistics (N,\%, Mean, Max, Min and SD) for the sample of organizations, which differ in origin, ownership of capital and activity. According to the criterion framework, the organizations in the sample differentiate according to the manifestation of the following approaches, as follows: the access of obstructionism to the SR manifests a total of $1.94 \%$ of the organizations, out of which $1.29 \%$ are organizations from the public sector with a service activity. $26.45 \%$ of organizations apply a defensive approach to the process of creating SR policies, of which $23.87 \%$ are public sector organizations and $2.58 \%$ are 
from the private sector. $34.84 \%$ of the organizations in the sample achieve an approach to adapting to the SR, of which $21.29 \%$ are private sector organizations and $13.59 \%$ are those from the public sector. The access, within the private sector, with the highest percentage $(10.97 \%)$ is achieved by organizations with foreign origin of capital and service activity, and in the public sector, $12.26 \%$ of organizations are in the service sector. A proactive approach to the process manifests $36.77 \%$ of the organizations in the sample, i.e. $31.61 \%$ of the private sector organizations and $5.16 \%$ of the public sector organizations. The largest percentage of them, or $10.32 \%$, are organizations with foreign origin of capital and production activity.

Table 3: Corporate Approach toward CSR

\begin{tabular}{|c|c|c|c|c|c|c|c|c|}
\hline \multirow{2}{*}{ 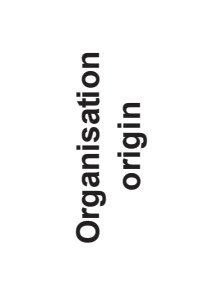 } & \multirow{2}{*}{ 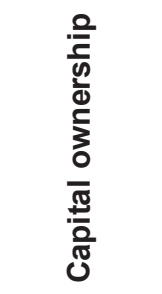 } & \multirow{2}{*}{ 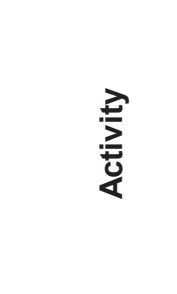 } & \multicolumn{6}{|c|}{ Descriptive statistics toward CSR policy creation } \\
\hline & & & $\mathrm{N}$ & $\%$ & M & Min & Max & SD \\
\hline \multirow{4}{*}{ Private sector } & \multirow[b]{2}{*}{ domestic } & service & 36 & 23.23 & 3.19 & 1.67 & 4.63 & 0.692434 \\
\hline & & production & 35 & 22.58 & 3.49 & 1.96 & 4.58 & 0.687356 \\
\hline & \multirow[b]{2}{*}{ foreign } & service & 8 & 5.16 & 3.56 & 2.65 & 4.4 & 0.699298 \\
\hline & & production & 8 & 5.16 & 3.58 & 2.79 & 4.58 & 0.686934 \\
\hline \multirow{2}{*}{\multicolumn{2}{|c|}{ Public sector }} & service & 63 & 40.65 & 3.00 & 1.23 & 4.76 & 0.741703 \\
\hline & & production & 5 & 3.23 & 3.25 & 2.1 & 3.91 & 0.702153 \\
\hline \multicolumn{3}{|c|}{ Total } & 155 & 100.00 & & & & \\
\hline
\end{tabular}

Table 3a: Corporate Approach toward CSR

\begin{tabular}{|c|c|c|c|c|c|c|}
\hline \multirow[b]{2}{*}{ 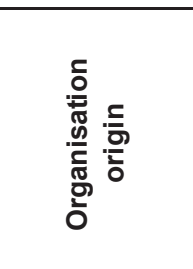 } & \multirow[b]{2}{*}{ 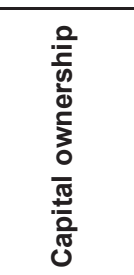 } & \multirow[b]{2}{*}{ 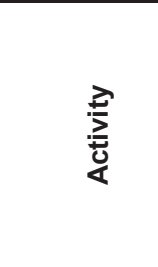 } & \multicolumn{4}{|c|}{ Corporate approach toward CSR } \\
\hline & & & $\begin{array}{l}\text { obstructionism } \\
\text { approach } \%\end{array}$ & $\begin{array}{c}\text { defensive } \\
\text { approach \% }\end{array}$ & $\begin{array}{c}\text { adjustment } \\
\text { approach } \%\end{array}$ & $\begin{array}{c}\text { proactive } \\
\text { approach \% }\end{array}$ \\
\hline \multirow{4}{*}{ Private sector } & \multirow[b]{2}{*}{ domestic } & service & 2.58 & 7.10 & 7.74 & 5.81 \\
\hline & & production & 0.65 & 3.23 & 11.61 & 7.10 \\
\hline & \multirow[b]{2}{*}{ foreign } & service & 0.00 & 1.29 & 1.94 & 1.94 \\
\hline & & production & 0.00 & 1.29 & 1.29 & 2.58 \\
\hline \multirow{2}{*}{\multicolumn{2}{|c|}{ Public sector }} & service & 4.52 & 18.06 & 14.84 & 3.23 \\
\hline & & production & 0.00 & 1.29 & 0.65 & 1.29 \\
\hline \multicolumn{3}{|c|}{ Total } & 7.74 & 32.26 & 38.06 & 21.94 \\
\hline
\end{tabular}

The descriptive statistics (N,\%, Mean, Max, Min, and SD) for public and private sector organizations derived using the cross-section for comparison according to the criterion: activity, ownership of capital, size of organizations by number employees. The data for the private sector organizations according to the stated criteria indicates the following: A defensive approach to the SR process as a negative trend compared to other organizations with $4.60 \%$ manifested by service organizations, with domestic capital and a medium size. Positive trends in the application of the adjustment approach show organizations with domestic capital, small organizations, out of which $12.60 \%$ are organizations with production activity, and $8.50 \%$ organizations with service activity. The proactive approach is applied by organizations with domestic capital, with service and manufacturing activity and with a large number of employees, which is $4.60 \%$ of them.

Descriptive statistics (N,\%, Mean, Max, Min and SD) obtained with the help of the cross tabulation for public sector organizations according to the criteria of activity and size of the 
organizations and number of employees indicate that: Negative trend in the application of the obstructionism approach show the organizations with service activity and medium size, and which are public institutions / public enterprises according to the ownership of the capital, i.e. $4.41 \% .11 .76 \%$ and $7.35 \%$ of the local government organizations with a service activity (small and medium size) show a positive trend in the application of the process of creating the SR policies as an adaptation approach. The proactive approach to the process of creating SR policies is applied by $4.41 \%$ of medium-sized service organizations and those are public institutions / public enterprises according to the ownership of capital.

\section{DISCUSSION}

The SR policies, both at the macro and micro level (national and organizational), are in function of the country's economic development policy and are considered within the entrepreneurship and in the context of securing the competitive advantage of the business community on the global market. SR policies are the highest strategic form for the implementation of the concept. With the help of the strategic approach to the SR, the advancement of corporate financial interests and the avoidance of remarks that management "wastes money" when it comes to investments in the interests of stakeholders that are not related to the core business of the organization is facilitated.

If investment in SR policies is considered as an investment for and into the future, then the approach that organizations use for SR contains an instrumental value on which the expectation is based that will contribute to increasing profitability. The approach that organizations from both sectors manifest to the SR is a reflection of the organization's ethical culture and the builtin responsibility in business operations and in the attributes of products / services, and is in the interests of the well-being of the stakeholders and the society as a whole. The SR approach reflects the level of integration of the SR policies into the corporate strategy through the four aspects, the focal point of which is the stakeholders, the balance and the dynamics between proactive ethics and the personal management interests. Relying on the opinion of Bernardis et al. (2009), we find the justification for the different approach of the organizations from the private and the public sector in the Republic of Macedonia to the process of creating the SR policies for three reasons: the different application of the policies and tools for the SR for the creation of values, the development of organizational abilities for the strategic alignment of the concept with the essential processes (i.e. integration of the concept of SR in the core business / business operations and processes), in particular in its strategy, and in the different financial perspectives of the organizations from the two sectors. In this regard is also the claim of Wyver et al. (Weaver et al., 1999), where, in the presence of a commitment to CSR driven by institutional forces, and without the commitment of management to CSR, the so-called "debased" SR activities appear, which are not related to the usual ongoing activities of the organization, which means, are not connected with the core business of the organization. Organizations from both sectors emphasize various aspects of social reports: the private sector focuses on sustainable profitability, while the public sector focuses on effectiveness based on the budgeting system. Entities from the public and private sectors also differ in the scope of the SR practices. The private sector uses CSR practices to demonstrate the sustainability of its business operations, while it depends on the ability of the public sector to produce public values and their sharing with stakeholders in a sustainable way.

The access of the organizations to the SR involved in the research depends on the area of their activities (health, social protection, education, child protection, energy, telecommunications, banking and finance, trade, food production and confectionery, etc.). However, organizations 
from the same field of action manifest a different approach to the SR due to the different contextual conditions in which they operate, which are determined by the specific competencies of the management, the different internal dynamics of the organizations, the different needs and expectations of the stakeholders, and from the nature of the activity (production or service). The different approach of the organizations towards the process of SR, considering their size (determined by the number of employees), ownership of capital, origin and activity, are due to several influential factors, such as:

- ownership of the capital (domestic, foreign, state / public), that is, the management of the organization by the owners / shareholders or officials (e.g., the system of selfmanagement)

- the high level of personalization from the aspect of the influence of personal attitudes and values of the owners / entrepreneurs / politicians (officials)

- the sociotropic character of the relationship with the community (Graafland et al, 2003) (reflects the power of collective thinking over the pattern of egocentric decision-making.) Sociotropic decisions rely on the attitude of how much of the pre-shared activities are "the right things" based on which do not require pure philanthropic activities of the SR or an approach that is independent of the strategic goals of the organization and the structural lack of resources

- the risk of potential economic loss when investing in the wrong form of the SR, especially in small and medium enterprises and in the attempt to prove and strengthen the connection with the community. The relationship between the SR policies and the economic goals of the organization is considered particularly important in identifying the link between the SR policies and the corporate / organizational strategy. Therefore, profit-making organizations that can invest in SR consider that it is best to focus on non-profit-related activities, such as proactive ethical activities (Stahl \& Grisby, 1997), the approach of the organization to interactive social control (Lamberi \& Noci, 2012), which refers to effective stakeholder dialogue based on the standards they set for channeling expectations. In the last decade, the focus of stakeholder theory is shifting towards social capital, the concept of social capital theory, which is considered the core of the relationship-organization environment, and it denotes the relationship between the individual / social network and the norms of mutual trust, commitment and reciprocity. Fuller \& Tain (2006) say that the greater the social capital, the greater the power of the dialogue with the environment. Possession of such capital is a tool for identifying the ethical and responsible behavior of the organization towards the internal and external environment, that is, towards different stakeholder groups.

The empirical data from the survey provided a picture of: a proactive approach to the SR and the approach to the adaptation of organizations from the private and public sector in RM to the SR. Applying the proactive approach to SR is a clear indication of the high level of management consciousness about the importance of the concept, for the development of the strategic integrative dimension of the SR. Organizations, relying on the instrumental values of the concept and responsibility for the consequences of their own actions, place the SR on ethical, economic and legal motives and take steps to provide support for sustainable development of the environment. Despite the reactive nature of communication with stakeholders in most organizations, the general approach to the SR points to the existence of a certain level of selfinitiative in terms of seeking opportunities for the development of social capital, which is an investment of own incomes in social initiatives (social, environmental, ethical aspects) with long-term effects. The proactive approach to the SR involves the implementation of the SR through various initiatives, programs and projects, and not only through the support of the community with a philanthropic dimension of the SR, that is, with donations. 
The basis for the development of the proactive approach to the SR to the highest level lies in the financial perspectives of private sector organizations coupled with the normative (legal) and moral ethical obligation to reinvest their own revenues. This demonstrates the step taken by private sector organizations to the creation of socially shared values to bridge the gap between the social environment and the SR, and, as Porter \& Kramer (2011) says, which capitalize on capitalism and its relationship with society.

One factor that plays a significant role in the development of the proactive approach is the transfer of know-how to the introduction of SR initiatives in business operations, FDI and the incentive for equal participation in the global market through the development of competitive advantage and the development of innovation to the level of good practice. Weaknesses in the development of access to public sector organizations are associated with: financial perspectives centralized budgeting system, profit / benefit management system, accountability to owners / shareholders for the spending of own funds and the nature of the needs of the stakeholders. The approach notes developmental dynamics in those organizations that profit from their activities, which do not have a strictly centralized budgeting system, which are regulated by a model of profit management, and which are service-oriented to the citizens.

In the shadow of organizations that have a proactive approach to the SR are the organizations dominated by the approach to adaptation to the SR. Organizations where the development of SR attains this level demonstrate a solid balance between their own ethical culture and stakeholders' interests, that is, a balance between ethical culture and the economic interests of the owners / shareholders. The approach to adjustment is dominantly represented in public sector organizations with service activities that are part of the local government. Opportunities for investment in SR initiatives are based on their own financial resources and on the realized profit, but they also rely on partnership relations with organizations from the private and civil sector. Hence, the creation of public values enriched with SR attributes and their sharing with stakeholders confirms the opinion of Bernardis et. al. (2011): "public sector organizations in this way provide their own sustainability and achieve market competitiveness". The development of the approach points to the positioning of the SR policies in organizational strategies among the four most important internal perspectives (operational processes, management practices, stakeholder management, users and innovation). Within the private sector, access is dominant in large organizations of foreign origin of the capital, which is confirmed by the approach to philanthropy and the realized donations to support the community.

The defensive approach to the SR has a dominant manifestation in public sector organizations with a service activity. These organizations achieve their responsibility for the consequences caused by their actions only within the legal requirements. In the interaction with stakeholders, they rely on the ethical dimension of the decisions and focus only on the interests and needs that are related to the core business, while not having an innovative approach to the development of the products / services.

An insignificant percentage of organizations in the sample show an obstructive approach to the $\mathrm{SR}$, which calls into question the existence of the organization.

\section{CONCLUSION}

From the conducted research in the private and public sector organizations in the Republic of Macedonia on the approach to the process of creating the SR policies, it can be concluded that 
the private sector organizations in the RM show a combined approach to the SR, a combination of the approach to adaptation and proactive approach that has a strategic character, unlike the public sector, which demonstrates a combination of dominant defense approach and adaptation approach, depending on the presence of the characteristics.

\section{REFERENCES}

[1] Porter, M. E. and M. R. Kramer: (2002). 'The Competitive Advantage of Corporate Philanthropy', Harvard Business Review

[2] Porter, M. and M. Kramer: 2006, "Strategy \& Society”, Harvard Business Review 84(12), 78-92

[3] Porter, Michael E., and Mark R. Kramer. "Creating Shared Value", Harvard Business Review 89, nos. 1-2 (January-February 2011): 62-77

[4] Militaru, G. and Ionescu, S (2006). THE COMPETITIVE ADVANTAGE OF CORPORATE SOCIAL RESPONSIBILITY. U.P.B. Sci. Bull., Series D, Vol. 68, No. 2, 2006

[5] Zadek, S. (2006). Corporate responsibility and competitiveness at the macro level: responsible competitiveness: reshaping global markets through responsible business practices. Corporate Governance, 6(4), pp. 334-348.

[6] Gaberman, B. (2007) A GLOBAL OVERVIEW OF CORPORATE SOCIAL RESPONSIBILITY. The John D. Gerhart Center for Philanthropy and Civic Engagement American University in Cairo Spring 2008.

[7] Jones, R. G., \& George, M. J. (2008) Contemporary management. Global communication.

[8] Visser, W (2006). Revisiting Carroll's CSR pyramid, Corporate citizenship in developing countries: new partnership perspectives, p. 29.

[9] Weaver, G. R., Treviño, L. K., \& Cochran, P. L. (1999). Corporate ethics programs as control systems: Influences of executive commitment and environmental factors. Academy of Management Journal, 42: 41-57

[10] Bernardis, De L., Carli, L., Maiolini, R., and Braccini, A., M. (2011). Corporate Social Responsibility in Private and Public Sector, Sustainability of business versus effectiveness of action. (Available at: Academia.edu)

[11] Stabel, C.B., Fjeldstad ØD (1998) Configuring value for competitive advantage: on chains, shops and networks. Strategic Management Journal, 19(55): 413-437. Bernardis, L., Maiolini, R., and Braccini, A. M. Corporate Social Responsibility in Private and Public Sector Sustainability of business versus effectiveness of action. Available at: https://www.academia.edu/1131793/Corporate_Social_Responsibility_in_Private_and_P ublic_Sector_Sustainability_of_business_versus_effectiveness_of_action (16.11.2013)

[12] Lamberti, L \& Noci, G. (2012) The relationship between CSR and corporate strategy in medium-sized companies: evidence from Italy. Business Ethics 21 (4):402-416 (2012)

[13] Fuller T. \& Tian, Y (2006). Social and Symbolic Capital and Responsible Entrepreneurship: An Empirical Investigation of SME Narratives.Journal of Business Ethics 67 (3):287 - 304. 